\title{
Partitioning of Iron and Scandium in Soils Having Water Drainage Limitations
}

\author{
Michael Aide, Indi Braden, and Wesley Mueller \\ Department of Agriculture, Southeast Missouri State University, One University Plaza, Cape Girardeau, MO 63701, USA \\ Correspondence should be addressed to Michael Aide, mtaide@semo.edu
}

Received 13 April 2009; Accepted 5 October 2009

Recommended by Sabine Goldberg

\begin{abstract}
Soil chemistry of Fe includes weathering reactions, adsorption, hydrolysis, complexation, and oxidation-reduction reactions. Soil chemistry for scandium (Sc) is similar, but Sc does not include oxidation-reduction reactions. To determine if geochemical analysis may be used to identify Sc partitioning with respect to Fe among the particle size fractions, two Alfisol and two Ultisol soils were assessed using an aqua-regia digestion to estimate $\mathrm{Sc}$ and Fe concentrations for whole soil and particle size separates. Aqua-regia digestion data showed Sc depletion relative to Fe in sand separate. Sand separate is largely composed on quartz sand and Fe-Mnbearing nodules, which are redoximorphic features produced by alternating oxic and suboxic/anoxic conditions associated with seasonally fluctuating water tables. Relative partitioning of Fe and Sc in these soils warrants further study to assess if selective extractions could quantify the extent of modern or ancestral oxidation-reduction processes responsible in some soil features involved in soil genesis.
\end{abstract}

Copyright (C) 2009 Michael Aide et al. This is an open access article distributed under the Creative Commons Attribution License, which permits unrestricted use, distribution, and reproduction in any medium, provided the original work is properly cited.

\section{Introduction}

Scandium (Sc) is the 21st element in the periodic table, having an $[\mathrm{Ar}] 3 \mathrm{~d}^{1} 4 \mathrm{~s}^{2}$ electronic configuration. The aqueous hydrolysis of $\mathrm{Sc}^{3+}$ should be very similar to that of $\mathrm{Fe}^{3+}$, given that both elements are first-row transition metals and their ionic radii are similar $\left(\mathrm{Sc}^{3+}\right.$ has an ionic radii of $0.08 \mathrm{~nm}$ and $\mathrm{Fe}^{3+}$ has an ionic radii of $0.09 \mathrm{~nm}$ ) [1]. The aqueous hydrolysis of $\mathrm{Sc}^{3+}$ is initiated at $\mathrm{pH} 2.5$ and the precipitation of its hydrolysis products is completed between $\mathrm{pH} 4$ and 5, implying that $\mathrm{Sc}^{3+}$ and $\mathrm{Fe}^{3+}$ have similar hydrolysis behaviors [2]. Aqueous hydrolysis products of Sc include $\mathrm{ScOH}^{2+}(\mathrm{pK}$ $=4.3), \mathrm{Sc}_{2}(\mathrm{OH})_{2}{ }^{2+}(\mathrm{pK}=6.0), \mathrm{Sc}_{3}(\mathrm{OH})_{5}{ }^{4+}(\mathrm{pK}=16.34)$, $\mathrm{Sc}(\mathrm{OH})_{2}{ }^{+}(\mathrm{pK}=9.7)$, and $\mathrm{Sc}(\mathrm{OH})_{3}(\mathrm{pK}=16.1)$. Baes and Mesmer [2] noted that $\mathrm{Sc}(\mathrm{OH})_{3}$ phase solubility proceeds as

$$
\mathrm{Sc}(\mathrm{OH})_{3(\text { solid })}=\mathrm{Sc}^{3+}+3 \mathrm{OH}^{-}, \quad \log \mathrm{K}_{\mathrm{s}}=-33.0
$$

Scandium substitutes for $\mathrm{Al}^{3+}, \mathrm{Fe}^{3+}, \mathrm{Y}^{3+}$, and $\mathrm{Ti}^{4+}$ in primary minerals, especially for inosilicates and biotite [3]. Scandium concentration ranges are largely dependent on the type of parent material: sandstone and limestone (0.5 to
$1.5 \mathrm{mg} \mathrm{Sckg}{ }^{-1}$ ), felsic igneous rocks (3 to $14 \mathrm{mg} \mathrm{Sc} \mathrm{kg}{ }^{-1}$ ), shale and argillaceous sediments ( 10 to $15 \mathrm{mg} \mathrm{Sc} \mathrm{kg}^{-1}$ ), and surface soil horizons ( 0.5 to $45 \mathrm{mg} \mathrm{Sc} \mathrm{kg}^{-1}$ ) [3].

Brown et al. [4] recently proposed using Fe/Sc ratios as an indicator for discriminating between oxidation-reduction induced Fe-accumulations and Fe-depletions in lateritic landscapes. Noting the high field strength of Sc, they predicted that Sc is generally associated with secondary Feoxyhydroxides, regardless of particle size. Using Sc as an index element, absolute Fe-accumulation was estimated as a deviation from an $\mathrm{Sc}-\mathrm{Fe}(x, y)$ linear relationship involving associated materials lacking any oxidation-reduction influences.

Iron is the 26th element of the Periodic Table, having an electronic configuration of $[\mathrm{Ar}] 3 \mathrm{~d}^{6} 4 \mathrm{~s}^{2}$. Iron is an exceptionally abundant element, possessing $\mathrm{Fe}^{2+}$ and $\mathrm{Fe}^{3+}$ oxidation states in octahedral coordination in a variety of primary and secondary minerals. The soil chemistry of Fe has been extensively reviewed [2, 5-7]. Comparison of the thermochemical data of Fe [6] with that of Sc [2] shows remarkable hydrolysis and solubility similarities. 
The ability of Fe to participate in oxidation-reduction reactions throughout a wide range of $\mathrm{pH}$ and $\mathrm{Eh}$ soil environments contrasts markedly with the solitary oxidation status of $\mathrm{Sc}^{3+}$. The reduction of $\mathrm{Fe}^{3+}$ and $\mathrm{Fe}(\mathrm{OH})_{1}{ }^{2+}$ may be written as

$$
\begin{gathered}
\mathrm{Fe}^{3+}+\mathrm{e}^{-}=\mathrm{Fe}^{2+}, \quad \mathrm{E}^{o}=0.770 \text { volts } \\
\mathrm{Fe}(\mathrm{OH})^{2+}+\mathrm{H}^{+}+\mathrm{e}^{-}=\mathrm{Fe}^{2+}+\mathrm{H}_{2} \mathrm{O}, \quad \mathrm{E}^{o}=0.899 \text { volts }
\end{gathered}
$$

where $\mathrm{Fe}^{3+}$-hydroxy coordination influences the reduction potential and allows acidic soil environments to maintain greater $\mathrm{Fe}^{2+}$ activities [6]. Thus, the soil environment may maintain seasonal anoxic soil conditions promoting $\mathrm{Fe}$ reduction and $\mathrm{Fe}-\mathrm{Sc}$ partitioning.

1.1. The Interaction of Sc and Fe in Soils. Soil conditions critical to Fe-Mn nodule formation include an alternating oxicanoxic regime, usually imposed by seasonal periods of wetness and restricted drainage [8-11]. During anoxic events, reduction reactions increase the $\mathrm{Fe}^{2+}$ activity, allowing $\mathrm{Fe}^{2+}$ transport (primarily diffusion). Oxic soil environments permit Fe-oxyhydroxides formation [12]. Many repeated cycles of Fe-reduction, Fe-transport, and Fe-oxidation gradually convert $\mathrm{Fe}$ originally occurring as dispersed $\mathrm{Fe}$ oxyhydroxides throughout the soil matrix to Fe-Mn-bearing nodules. With time, these Fe-Mn nodules increase in size and texturally exist as a portion of the sand separate, whereas the surrounding soil matrix becomes increasingly Fe-depleted. Fe-oxyhydroxides are also commonly associated with the clay separate. The enhanced surface areas of phyllosilicate minerals provide a favorable template for Fe-oxyhydroxide synthesis. Because Fe-oxyhydroxide-clay associations have been observed in well-drained soils, the requirement of seasonal anoxic to suboxic soil conditions is not necessary for Fe-oxyhydroxide formation on phyllosilicate surfaces.

Scandium, given its similar chemistry with that of Fe, should participate in adsorption and precipitation reactions and should yield a consistent compositional presence with $\mathrm{Fe}$ in Fe-oxyhydroxides in the silt and clay fractions. The presence of Fe-Mn-bearing nodules in the sand fabric, because of its greater reliance on alternating oxic-anoxic soil conditions, should reveal a relative Sc-depletion. Iron/Sc ratios among the horizons of a soil profile may not be consistent because of pedogenic processes that allow Sc and Fe partitioning among the particle size fractions. Additionally, changes in the Fe/Sc ratio across soil boundaries may occur because of (1) changes in parent materials, (2) the soil's natural $\mathrm{Fe}$ and $\mathrm{Sc}$ variability in individual soil horizons, (3) eluviation-illuviation processes, (4) the selection of experimental protocols, and (5) soil pollution.

The purpose of this investigation is to evaluate the $\mathrm{Fe}$ and Sc aqua regia digestion concentration distributions between the whole soil and the sand, silt, and clay separates to document a preferential $\mathrm{Sc} / \mathrm{Fe}$ depletion in the sand separate.

\section{Materials and Methods}

2.1. Study Area. The soils are located in southeastern Missouri with two pedons representing the Alfisol order and two pedons representing the Ultisol order. The Alfisol and Ultisol pedons were located, described, and sampled in undisturbed forest settings using excavated pits according to Soil Survey Division Staff $[13,14]$. The Alfisol pedons were located in a remote region of Mingo National Wildlife Refuge in southeastern Missouri. USDA-NRCS communicated that the soil survey was more of a reconnaissance survey, whereas the Ultisol pedons were located and described by USDA-NRCS personnel. Samples were air-dried and sieved to remove fragments greater than $2 \mathrm{~mm}$. The climate is continental and humid, with soils maintaining mesic (Ultisols) to thermic (Alfisols) soil temperature regimes and udic (Ultisols) and aquic (Alfisols) soil moisture regimes.

2.2. Laboratory Analysis. Soil $\mathrm{pH}$ in water, total acidity by titration, exchangeable cations by $1 M \mathrm{NH}_{4} \mathrm{OAc}(\mathrm{pH}$ 7.0) extraction are routine procedures cited in Carter [15]. The cation exchange capacity (CEC) was calculated by summation of exchangeable cations and total acidity. The clay, silt, and sand fractions were separated by Nasaturation of the exchange complex, washing with watermethanol mixtures, dispersion in $\mathrm{Na}_{2} \mathrm{CO}_{3}(\mathrm{pH} 9.2)$, followed by centrifuge fractionation, and wet sieving [15].

Aqua-regia digestions of the fine earth fraction and the particle size separates were employed to obtain a near total estimation of elemental abundance associated with all but the most recalcitrant soil chemical environments. Aquaregia digestion does not appreciably degrade quartz, albite, orthoclase, anatase, barite, monazite, sphene, chromite, ilmenite, rutile, and cassiterite; however, anorthite and phyllosilicates are partially digested. Homogenized samples $(0.75 \mathrm{~g})$ were equilibrated with $0.01 \mathrm{~L}$ of aqua-regia $\left(3 \mathrm{HNO}_{3}\right.$ : $\mathrm{HCl})$ in a $35^{\circ} \mathrm{C}$ incubator for 24 hours. Samples were shaken, centrifuged, and filtered $(0.45 \mu \mathrm{m})$, with a known aliquot volume analyzed using inductively coupled plasmamass spectrometry (ICP-MS). The aqua-regia digestion procedure was performed by Activation Laboratories (Toronto, Canada). (All trade names and product lines are mentioned solely for the benefit of readers, and do not imply endorsement). In this procedure selected samples were duplicated, and known reference materials were employed to guarantee analytical accuracy.

2.3. Data Presentation. Linear regression analysis and Pearson correlation analysis were performed using Excel.

\section{Results}

3.1. Soil Profile Descriptions. The Aqualf pedons (very wet Alfisols) are deep, poorly-drained soils located in backswamp environments having A-E-Btg-BCg soil horizon sequences (coarse-loamy (pedon 1) and fine-silty (pedon 2), mixed, superactive, thermic Typic Endoaqualfs). The loam and silt loam eluvial horizons are acid, whereas the silty clay loam 
argillic horizons range from medium acid in the uppermost portions to neutral and moderately alkaline in the lower portions. The argillic horizons have low chroma matrix colors with few to many higher chroma secondary colors. Few-to-common Fe-Mn masses were evident throughout the soil profiles, especially in the argillic horizon. Table 1 lists pertinent routine soil characterization data for each soil horizon, including $\mathrm{pH}$, total acidity, $\mathrm{CEC}$, and texture.

The Scholten (Fragiudults) pedons (Loamy-skeletal, siliceous, active, mesic Typic Fragiudults) reside in rolling to deeply dissected upland landscapes having A-E-Bt$2 \mathrm{Btx}-3 \mathrm{Bt}$ soil horizons sequences. The pedons are very deep, moderately well-drained Ultisols having a fragipan at approximately $1.0 \mathrm{~m}$. The pedons have an ochric-argillic sequence formed in loess overlying a fragipan-argillic horizon sequence developed in dolomitic residuum. The permeability is moderate above the fragipan, very slow in the fragipan, and moderately rapid below the fragipan. The strongly acid to very strongly acid pedons have gravelly to very gravelly silt loam textures in the eluvial and Bt horizons, whereas fragipan horizons have very gravelly loam textures. The deeper 3Bt horizons have very gravelly sandy clay loam to very gravelly clay textures. The eluvial and Bt horizons have dark grayish brown (10YR4/2) to yellowish brown (10YR5/6) colors, which contrast with the light brownish gray (10YR6/2) and light gray (10YR7/1) matrix colors of the fragipan. A more complete description of the sampled pedons may be found in Aide et al. [16].

3.2. Whole Soil Aqua-Regia Digestion Concentrations of Fe and $S c$. Iron is the most abundant transition metal in the soil environment, often showing accumulation in the argillic horizon because of eluviation-illuviation of $\mathrm{Fe}-$ oxyhydroxides associated with clay. The Alfisol and Ultisol pedons show greater Fe concentrations in the argillic horizon than the overlying eluvial horizons (Figures 1 and 2). The Scholten (Fragiudults) pedons show smaller Fe concentrations in the fragipan (2Btx) horizons than the overlying $\mathrm{Bt}$ horizons and underlying 3Bt horizons, a feature partially attributed to inherited parent material differences and partially attributed to redoximorphic processes. Whole soil AR digestion Sc concentrations generally parallel those of Fe, showing greater argillic horizon Sc concentrations (Figures 3 and 4). The dramatically greater Fe and Sc concentrations in the $3 \mathrm{Bt} 2$ horizon of the Scholten (Fragiudults) pedon\#2 may represent inherited differences attributed to the lithologic discontinuity.

The mean soil profile Fe soil horizon concentrations are 16,000 and $17,400 \mathrm{mg} / \mathrm{kg}$ for the Aqualf pedons and 18200 and $31200 \mathrm{mg} / \mathrm{kg}$ for the Scholten (Fragiudults) pedons. The mean soil profile Sc horizon concentrations are 3.5 and $3.6 \mathrm{mg} / \mathrm{kg}$ for the Aqualf pedons and 1.8 and $2.7 \mathrm{mg} / \mathrm{kg}$ for the Scholten (Fragiudults) pedons (Table 2). The 3Bt2 horizon in the Scholten (Fragiudults) pedon 2 shows dramatically greater $\mathrm{Fe}$ and Sc concentrations, reflecting the lithologic discontinuity. The rather large coefficients of variations are largely attributed to bimodal Fe and Sc concentration distributions between the eluvial and argillic horizons.

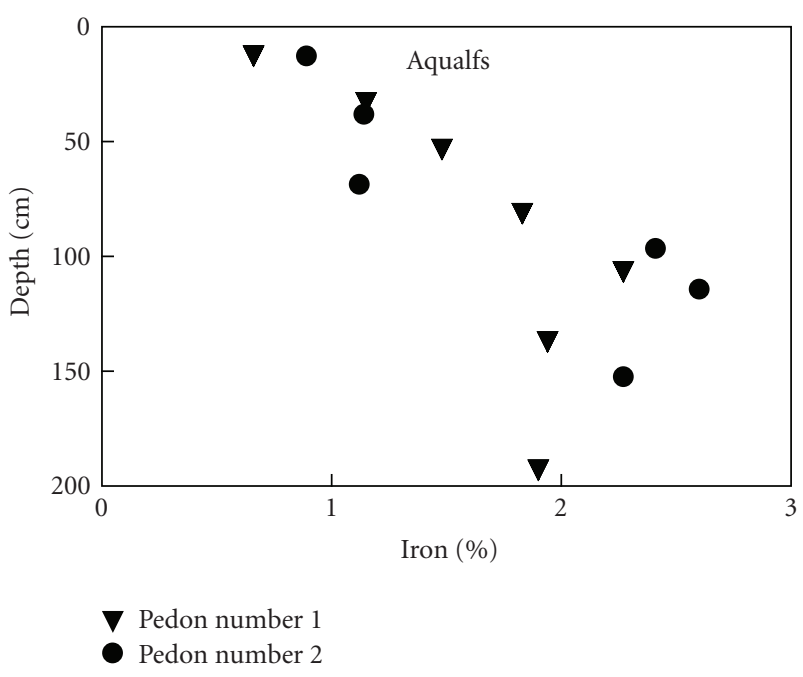

Figure 1: Soil profile Fe depth distribution for the Aqualf pedons.

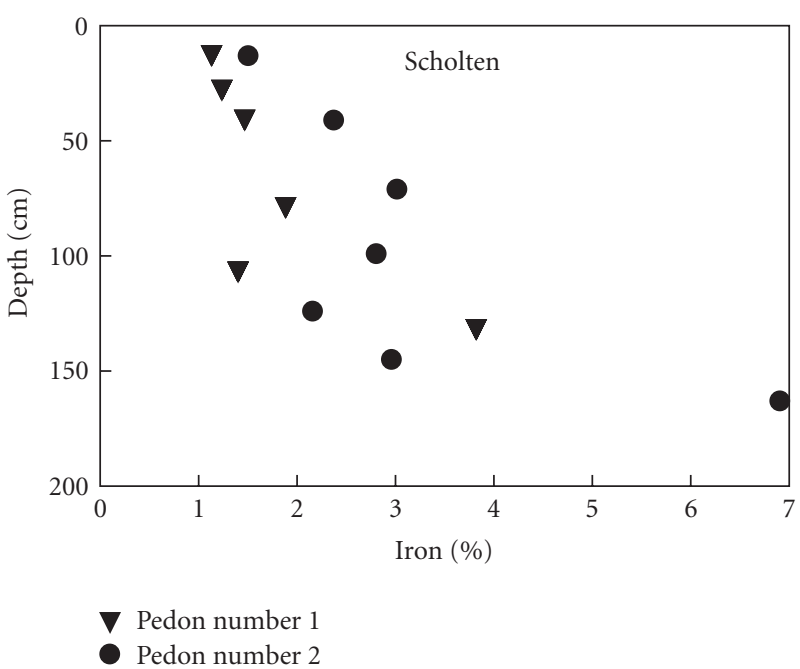

Figure 2: Soil profile Fe depth distribution for the Scholten (Fragiudults) pedons.

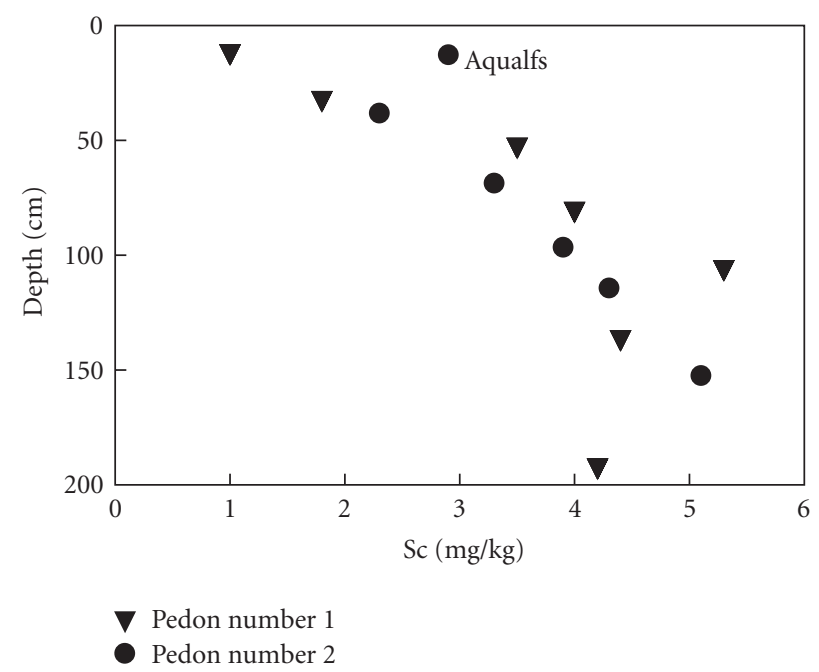

FIGURE 3: Soil profile Sc depth distribution for the Aqualf pedons. 
TABLE 1: Soil profile characterization.

\begin{tabular}{|c|c|c|c|c|c|}
\hline Horizon & $\begin{array}{c}\text { Depth } \\
\mathrm{cm}\end{array}$ & $\mathrm{pH}$ & Texture & $\mathrm{cmol} / \mathrm{kg}$ & CEC \\
\hline \multicolumn{6}{|l|}{ Aqualf\#1 } \\
\hline A & 13 & 4.1 & sandy loam & 2.0 & 5.8 \\
\hline $\mathrm{E}$ & 33 & 6.5 & loam & 1.7 & 9.5 \\
\hline Btg1 & 53 & 8.3 & loam & 0.1 & 18.1 \\
\hline Btg2 & 81 & 7.9 & loam & 0.0 & 22.9 \\
\hline Btg3 & 107 & 7.8 & loam & 0.0 & 21.8 \\
\hline Btg 4 & 137 & 7.3 & sandy loam & 0.1 & 18 \\
\hline $\mathrm{BCg}$ & 193 & 7.0 & loam & 0.2 & 20.3 \\
\hline \multicolumn{6}{|l|}{ Aqualf\#2 } \\
\hline Oi & 13 & 4.7 & - & 13.0 & 48.2 \\
\hline A & 26 & 5.2 & silt loam & 1.4 & 20.5 \\
\hline $\mathrm{E}$ & 51 & 5.2 & silt loam & 1.6 & 21.4 \\
\hline Btg1 & 82 & 5.8 & silty clay loam & 0.6 & 37.0 \\
\hline Btg2 & 110 & 7.0 & silty clay loam & 0.5 & 31.7 \\
\hline Btg3 & 127 & 7.1 & silt loam & 0.4 & 33.7 \\
\hline $\mathrm{Cg}$ & 165 & 7.6 & silt loam & 0.4 & 27.1 \\
\hline \multicolumn{6}{|c|}{ Scholten (Fragiudults)\#1 } \\
\hline A & 13 & 4.6 & silt loam & 18.8 & 19.8 \\
\hline E & 28 & 5.0 & silt loam & 5.8 & 7.3 \\
\hline Bt1 & 41 & 5.0 & silt loam & 4.7 & 6.4 \\
\hline $\mathrm{Bt} 2$ & 79 & 4.9 & silt loam & 9.5 & 11.6 \\
\hline $2 \mathrm{Btx}$ & 107 & 4.6 & loam & 6.7 & 8.8 \\
\hline $3 \mathrm{Bt} 1$ & 132 & 4.6 & sandy clay loam & 8.2 & 8.9 \\
\hline $3 \mathrm{Bt} 2$ & 173 & 4.7 & sandy clay & 9.9 & 10.4 \\
\hline \multicolumn{6}{|c|}{ Scholten (Fragiudults)\#2 } \\
\hline A & 13 & 4.8 & silt loam & 12.5 & 13.5 \\
\hline $\mathrm{E}$ & 41 & 5.0 & silt loam & 5.3 & 8.3 \\
\hline Bt1 & 71 & 4.9 & silt loam & 4.6 & 5.6 \\
\hline 2Btx1 & 99 & 4.9 & loam & 7.4 & 9.7 \\
\hline $2 \mathrm{Btx} 2$ & 124 & 4.9 & loam & 7.6 & 9.7 \\
\hline $3 \mathrm{Bt} 1$ & 145 & 4.8 & clay loam & 9.9 & 11.3 \\
\hline $3 \mathrm{Bt} 2$ & 163 & 4.6 & clay & 12.3 & 13.9 \\
\hline
\end{tabular}

All of the horizons of the Scholten (Fragiudults) pedons are gravelly to extremely gravelly.

TABle 2: Mean soil horizon Fe and Sc concentration statistics.

\begin{tabular}{|c|c|c|c|c|c|c|}
\hline \multirow[b]{2}{*}{ Soil } & \multirow[b]{2}{*}{ Pedon\# } & \multicolumn{2}{|c|}{ Mean } & \multicolumn{2}{|c|}{$\mathrm{CV}$} & \multirow{2}{*}{$\begin{array}{c}\text { Fe-Clay } \\
r^{2} \\
\end{array}$} \\
\hline & & $\mathrm{Fe}$ & $\mathrm{Sc}$ & $\mathrm{Fe}$ & Sc & \\
\hline & & & & $\%$ & $\%$ & \\
\hline \multirow[t]{2}{*}{ Aqualf } & 1 & 16000 & 3.5 & 34 & 44 & ns \\
\hline & 2 & 17400 & 3.6 & 44 & 28 & ns \\
\hline Scholten & 1 & 18200 & 1.8 & 55 & 20 & 0.9 \\
\hline (Fragiudults) & 2 & 31000 & 2.7 & 57 & 61 & 0.77 \\
\hline
\end{tabular}

Detection Limit. Fe is $100 \mathrm{mg} / \mathrm{kg}$ and Sc is $0.1 \mathrm{mg} / \mathrm{kg}$.

$\mathrm{CV}$ is the coefficient of variation.

ns indicates no significant Pearson correlations. 


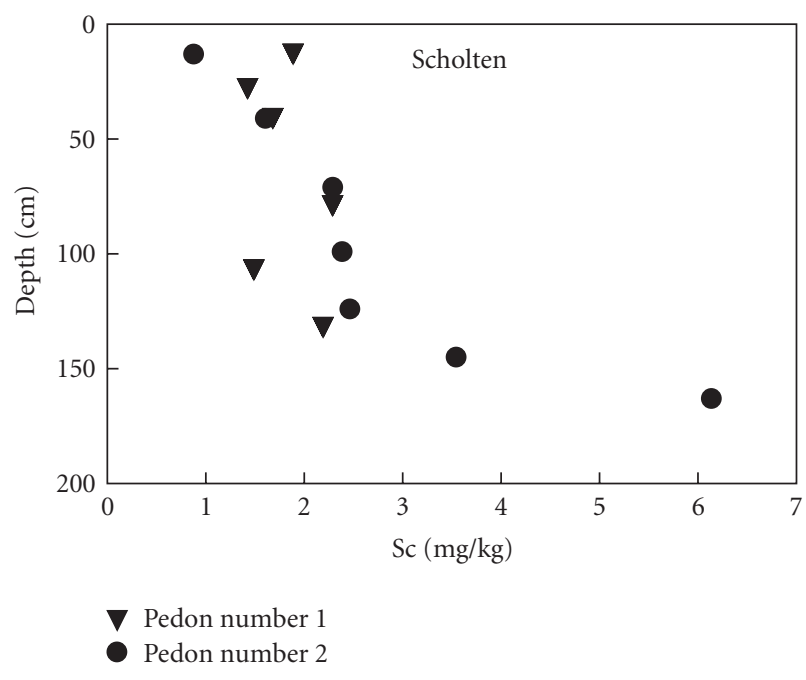

FIgURE 4: Soil profile Sc depth distribution for the Scholten (Fragiudults) pedons.

Iron concentrations show significant and positive correlations with clay contents in the Scholten (Fragiudults) pedons, whereas the poorly drained Aqualf pedons show no significant relationships between Fe concentrations and clay contents (Table 2). The lack of Fe-clay correlation in the Aqualf pedons is largely attributed to gleziation processes in the Btg and BCg horizons; that is, microbially mediated soil processes that chemically reduce $\mathrm{Fe}$-oxyhydroxides and permit $\mathrm{Fe}^{2+}$ removal from the soil in migrating leachate water [5].

3.3. Iron and Sc Partitioning among the Particle Size Separates. The Aqualf pedons have an abundance of Fe-Mn masses. The Sc/Fe sand fraction ratios in the Aqualf pedons are substantially smaller than the corresponding whole soil $\mathrm{Sc} / \mathrm{Fe}$ ratios (Figure 5), suggesting that Sc has been relatively depleted in the sand fraction. The particle size fractions of the Scholten (Fragiudults) pedons display: (i) relatively small $\mathrm{Fe}$ and $\mathrm{Sc}$ concentrations and relatively small $\mathrm{Sc} / \mathrm{Fe}$ ratios in the silt fraction, (ii) correspondingly small Sc and large $\mathrm{Fe}$ concentrations and relatively small $\mathrm{Sc} / \mathrm{Fe}$ ratios in the sand fraction, and (iii) large Fe and Sc concentrations and large $\mathrm{Sc} / \mathrm{Fe}$ ratios in the clay fraction (Figure 6). The Alfisol and Ultisol pedons show smaller sand separate $\mathrm{Sc} / \mathrm{Fe}$ ratios, implying that soil processes combined to effectively limit Sc incorporation into the sand separate's Fe-oxyhydroxides.

\section{Discussion}

The clay fraction's greater surface area preferentially promotes Fe oxyhydroxide formation $[5,17,18]$. The similar Sc and Fe hydrolysis and the nearly identical ionic radii of $\mathrm{Fe}$ and Sc should allow easy Sc substitution into the Feoxyhydroxide lattice. Conversely, small Fe-Mn-bearing sandsize nodules in the Aqualf pedons arise primarily from $\mathrm{Fe}^{2+}$ scavenging of the soil surrounding the Fe-Mn masses during anoxic conditions and the subsequent reconstitution of $\mathrm{Fe}^{3+}$

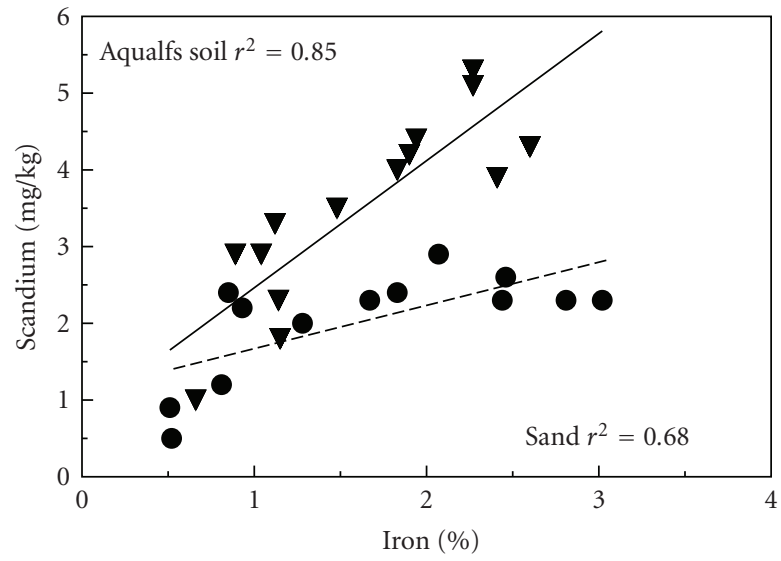

Figure 5: Scandium-iron distribution for the Aqualf pedons.

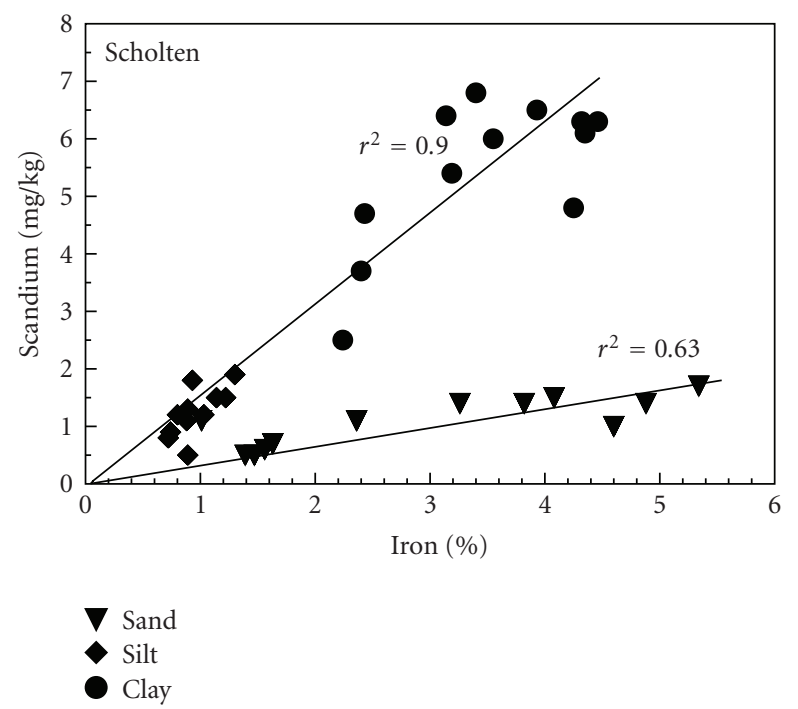

FIGURE 6: Scandium-iron distribution for the Scholten (Fragiudults) pedons.

in the Fe-Mn masses during the onset of oxic soil conditions. Scandium does not participate in oxidation-reduction processes and, therefore, $\mathrm{Sc}$ is not as equally represented as $\mathrm{Fe}$ in Fe-Mn masses. Conversely, Fe-oxyhydroxides associated with the silt and clay fractions do not exhibit relative Sc depletion and their formation is more consistent with $\mathrm{Fe}-\mathrm{Sc}$ hydrolysis and precipitation reactions, without recourse to seasonal anoxic soil conditions.

The Scholten (Fragiudults) pedons possess occasional Fe-Mn nodules throughout the soil profile; however, the majority of the Fe-oxyhydroxides in the sand separate appear as Fe-oxyhydroxide coatings on quartz sand grains. The Fe particle size distribution shows that the clay and sand separates have greater Fe concentrations than the silt separate. Thus, particle size segregation of Fe has occurred throughout the soil profile; however, the Fe-oxyhydroxide synthesis resulted primarily as $\mathrm{Fe}$-coatings rather than $\mathrm{Fe}$ $\mathrm{Mn}$ nodules. The Sc/Fe ratio of the sand separate indicates Sc depletion relative to $\mathrm{Fe}$, a feature consistent with nodule 
formation in the sand separate of the Aqualf pedons. The limited drainage imposed by the fragipan imposes restricted drainage and suboxic conditions periods; however, these suboxic conditions may not have the periodicity or intensity of duration as observed for the Aqualf pedons, thus $\mathrm{Fe}$ $\mathrm{Mn}$ nodules are not as readily formed. However, suboxic conditions may be sufficient to allow a smaller degree of Sc incorporation into Fe-oxyhydroxides in the sand separate, but caution may be warranted because other pedogenic processes attributed to parent material differences may be important; such as the $3 \mathrm{Bt} 2$ horizon of the Scholten (Fragiudults) pedon 2.

\section{Conclusion}

Scandium and Fe have nearly identical ionic radii and their hydrolysis behavior is remarkably similar; thus, Sc is frequently associated with $\mathrm{Fe}$ in the soils because of lattice substitution. A point of chemical departure between Fe and Sc occurs when Fe experiences oxidation-reduction episodes, resulting in soil Fe-Mn nodule formation. These nodules typically show preferential depletion of Sc relative to Fe when compared with the whole soil or the silt-clay separates. Future research may be able to utilize Sc partitioning to estimate the intensity of selected redoximorphic soil processes.

Differences in the whole soil $\mathrm{Sc} / \mathrm{Fe}$ ratios were not observed because of clay eluviation-illuviation processes, presumably because the amount of clay migration is limited and the clay fraction shows a similar $\mathrm{Sc} / \mathrm{Fe}$ ratio. The assumption that the whole soil and clay fraction $\mathrm{Sc} / \mathrm{Fe}$ ratio are always similar when applied to other soils is not warranted. Additionally, caution must be exercised in soils having lithologic discontinuities because of inherited Sc and $\mathrm{Fe}$ differences. Indeed, future research may show that $\mathrm{Fe} / \mathrm{Sc}$ ratios may differentiate or corroborate the placement of lithologic discontinuities.

\section{References}

[1] J. D. Lee, Concise Inorganic Chemistry, Chapman \& Hall, New York, NY, USA, 1991.

[2] C. F. Baes and R. E. Mesmer, The Hydrolysis of Cations, WileyInterscience, New York, NY, USA, 1976.

[3] A. Kabata-Pendias, Trace Elements in Soils and Plants, CRC Press, Boca Raton, Fla, USA, 2nd edition, 2001.

[4] D. J. Brown, P. A. Helmke, and M. K. Clayton, "Robust geochemical indicies for redox and weathering on a granitic laterite landscape in central Uganda," Geochimica et Cosmochimica Acta, vol. 67, pp. 2711-2723, 2003.

[5] U. Schwertmann and R. M. Taylor, "Iron oxides," in Minerals in Soil Environments, J. B. Dixon and S. B. Weed, Eds., Soil Science Society of America Book Series 1, Soil Science Society of America, Madison, Wis, USA, 1989.

[6] D. Langmuir, Aqueous Environmental Geochemistry, PrenticeHall, Upper Saddle River, NJ, USA, 1997.

[7] M. E. Essington, Soil and Water Chemistry: An Integrative Approach, CRC Press, Boca Raton, Fla, USA, 2004.
[8] U. Schwertmann and D. S. Fanning, "Iron-manganese concretions in hydrosequences of soils in loess in Bavaria," Soil Science Society of America Journal, vol. 40, pp. 731-739, 1976.

[9] G. A. Uzochukwu and J. B. Dixon, "Manganese oxide minerals in nodules of two soils of Texas and Alabama," Soil Science Society of America Journal, vol. 50, no. 5, pp. 1358-1363, 1986.

[10] M. Zhang and A. D. Karathanasis, "Characterization of ironmanganese concretions in Kentucky Alfisols with perched water tables," Clays and Clay Minerals, vol. 45, no. 3, pp. 428439, 1997.

[11] F. Liu, C. Colombo, P. Adamo, J. Z. He, and A. Violante, "Trace elements in manganese-iron nodules from a Chinese Alfisol," Soil Science Society of America Journal, vol. 66, no. 2, pp. 661670, 2002.

[12] S. W. Buol, F. D. Hole, R. F. McCracken, and R. J. Southard, Soil Genesis and Classification, Iowa State University Press, Ames, Iowa, USA, 1997.

[13] Soil Survey Division Staff, Soil Survey Manual, USDA Handbook, no. 18, U.S. Government Printing Office, Washington, DC, USA, 1993.

[14] Soil Survey Division Staff, "Official soil series descriptions,” USDA-NRCS, 2007, http://soils.usda.gov/technical/ classification/osd/index.html.

[15] M. R. Carter, Soil Sampling and Methods of Analysis, Lewis, Boca Raton, Fla, USA, 1993.

[16] M. T. Aide, D. Dunn, and G. Stevens, "Fragiudults genesis involving multiple parent materials in the eastern Ozarks of Missouri," Soil Science, vol. 171, no. 6, pp. 483-491, 2006.

[17] J. M. Bigham, D. C. Golden, S.W. Buol, S. B. Weed, and L. H. Bowen, "Iron oxide mineralogy of well-drained Ultisols and Oxisols: II. Influence of color, surface area, and phosphate retention," Soil Science Society of America Journal, vol. 42, pp. 825-830, 1978.

[18] J. M. Bigham, S. E. Heckendorn, W. F. Jaynes, and N. E. Smeck, "Stability of iron oxides in two soils with contrasting colors," Soil Science Society of America Journal, vol. 55, no. 5, pp. 14851492, 1991. 

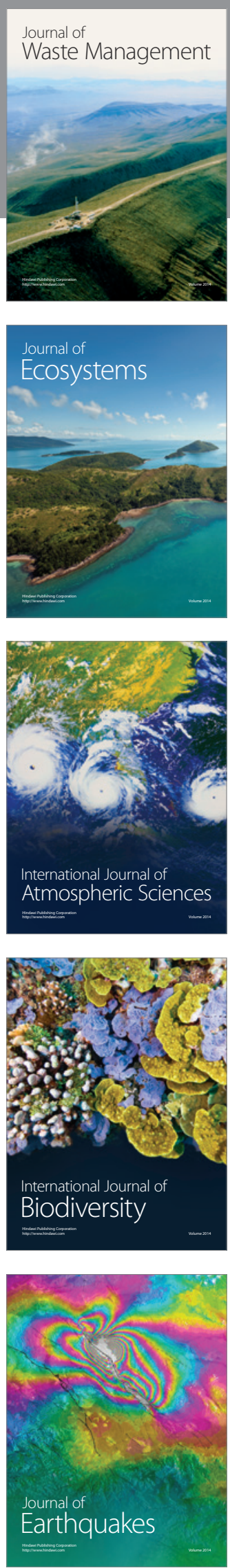
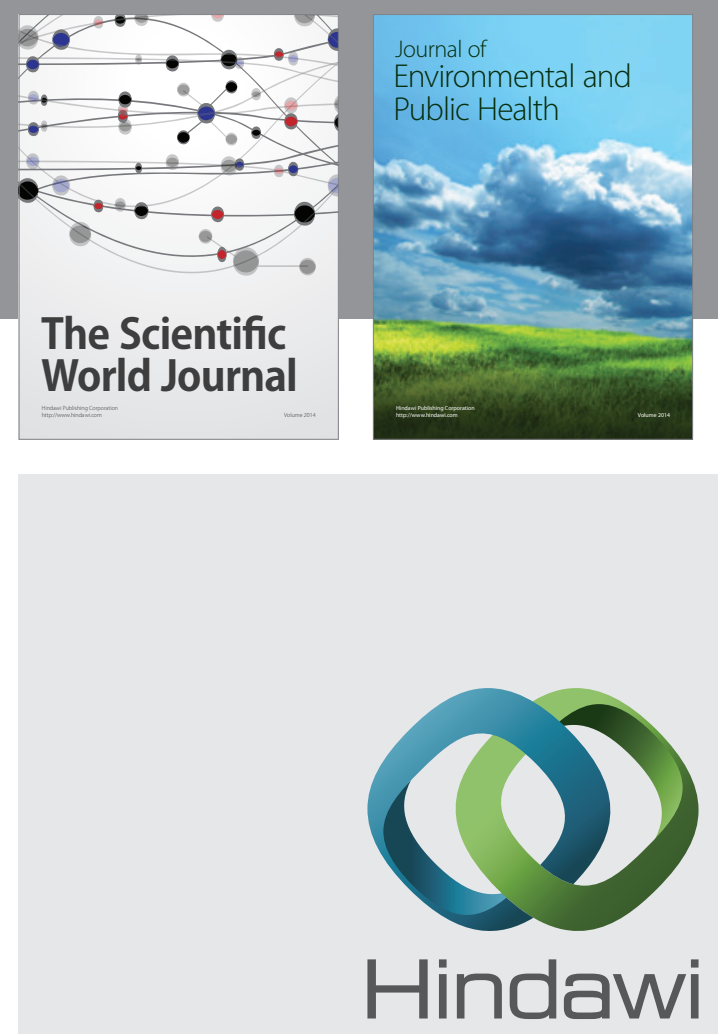

Submit your manuscripts at

http://www.hindawi.com
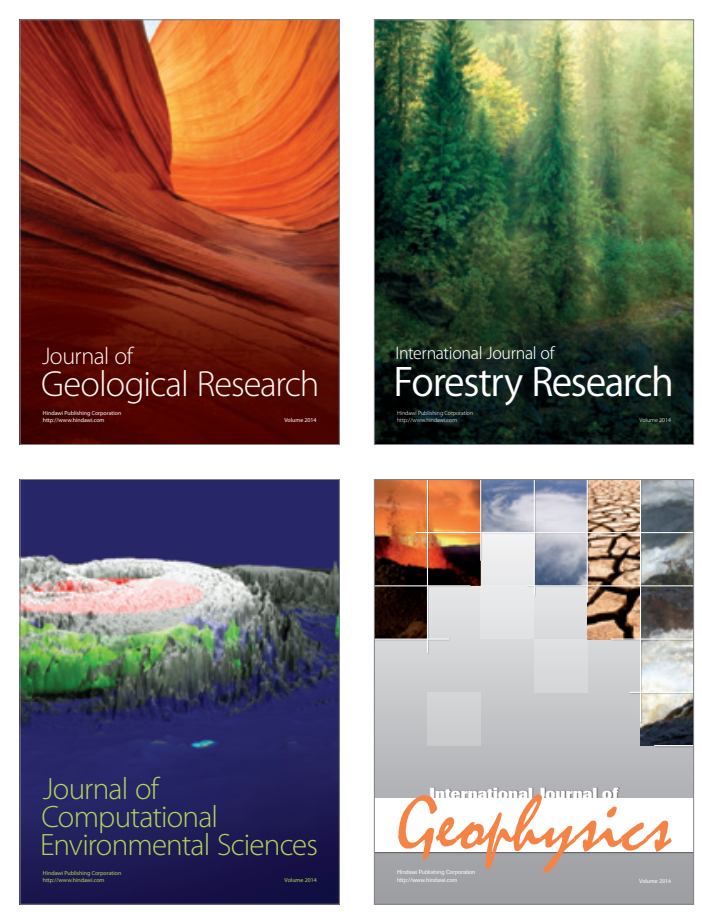
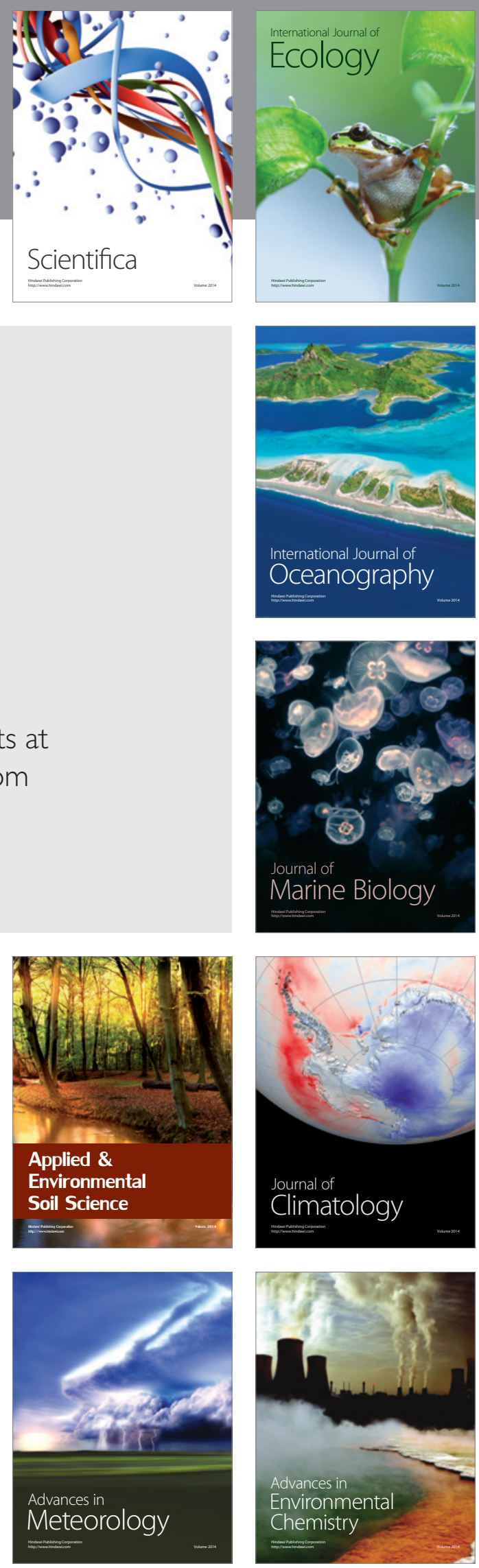